\title{
Strategi Pengadaan Bahan Non Buku Di Perpustakaan Universitas Negeri Padang Pada Era Revolusi 4.0
}

\author{
Atikah Aulia , Rahma Diani Ayudian Putri, Titin Tri Andini, Elva Rahmah \\ Program Studi Perpustakaan Dan Ilmu Informasi, Fakultas Bahasa dan Seni, Universitas Negeri Padang \\ Email: atikaha031@gmail.com
}

\begin{abstract}
This study aims to determine the strategy of procurement of non-book material in the central library of the state university of padang that can raise procurement and constraints in implementing strategies in the revolutionary era 4.0. this type of research is a qualitative approach with a method of interviewing the head of the padang state university library and staff management staff, library research by collecting data from reference materials, archives, and documents related to this research. The result of this study are the fact that in the central library of the state university of padang procurement of non-book material is no longer used because of the lack of a place for non-book material media such as tools, so people search for and obtain material or material on the internet that occurred in the revolutionary era 4.0.
\end{abstract}

Keywords: (strategy, procurement of non-book material, revolutionary era 4.0)

\section{PENDAHULUAN}

Perpustakaan diperguruan tinggi merupakan tempat atau pusat informasi dari sebuah universitas. Tempat mencari informasi, pengetahuan, dan ilmu dan segala informasi yang dibutuhkan oleh mahasiswa dalam menunjang proses perkuliahan. Oleh karena itu sebaiknya suatu perpustakaan universitas menyediakan bahan pustaka yang lengkap mulai dari pengadaan buku, terbitan berseri, dan bahan non buku.

Disetiap Perpustakaan perguruan tinggi digunakan sebagai sarana penunjang melaksanakan tugas pendidikan/pengajaran agar dapat melaksanakan proses belajar mengajar yang dinamis. Perpustakaan perguruan tinggi merupakan pusat informasi yang wajib memberikan berbagai jenis bahan pustaka, dengan koleksi yang lengkap, perpustakaan perguruan tinggi juga dapat berfungsi sebagai sarana belajar, sebagai sumber informasi, sebagai sumber hiburan, dan sarana untuk mencapai tujuan dalam pendidikan.

Dalam melakukan pengadaan bahan non buku diperlukan seleksi terlebih dahulu, supaya dapat dilakukan evaluasi dari segi isi maupun fisik bahan pustaka tersebut. Untuk melakukan seleksi bahan non buku diperlukan pengetahuan tentang non buku dan apa yang akan diseleksi. Macam-macam jenis bahan non buku seperti rekaman suara, rekaman video, bahan grafik, bahan katografi, bentuk mikro dan sumber daya elektronik.

Bahan non buku merupakan bahan pustaka yang perlu ditangani secara spesifik dalam pengelolaannya mulai dari seleksi, pengadaannya, pengolahan, penyimpanan dan layanan yang diberikan. Pada era revolusi 4.0 sekarang ini perkembangan ilmu pengetahuan dan 
Published by Program Studi Perpustakaan dan IImu Informasi

FBS Universitas Negeri Padang, Indonesia

teknologi yang sangat pesat dan memberikan dampak yang besar terhadap kehidupan manusia. Banyak yang terjadi dalam memudahkan dan pembaruan yang diperoleh dengan adanya dukungan teknologi digital. Layanan menjadi lebih cepat dan efisien serta memiliki jangkauan koneksi yang lebih luas dengan sistem online sehingga lebih mudah dalam menemukan informasi.

\section{METODE}

Metodologi yang digunakan pada penelitian ini adalah:

1. Obyek Penelitian

Obyek penelitian dari penelitian ini adalah perpustakaan pusat Universitas Negeri Padang

2. Teknik Pengumpulan Data

Teknik pengumpulan data yang dilakukan dalam penelitian ini adalah sebagai berikut :

a. Observasi Dengan melakukan wawancara kepada kepala perpustakan dan

b. Studi Pustaka dengan pengumpulan data dari bahan-bahan referensi, arsip, dan dokumen yang berhubungan dalam penelitian ini.

\section{HASIL DAN PEMBAHASAN}

A. Strategi Pengadaan Bahan Non Buku

Strategi adalah suatu rencana yang memiliki sistem pembauran tujuantujuan utama, kebijakan-kebijakan dan rangkaian tindakan dalam suatu organisasi menjadi satu kesatuan yang utuh. Strategi jika direalisasikan dengan baik, akan membantu penyusunan dan mengalokasikan sumber daya yang dimiliki perpustakaan dimanapun menjadi suatu bentuk yang unik, banyak diminati dan bertahan. Tanpa adanya strategi suatu rencana tidak akan berjalan baik, stategi juga diperlukan dalam suatu kegiatan perencanaan dalam hal apapun. Strategi perpustakaan adalah suatu rumusan pion-poin garis besar keputusan dan tindakan yang ditetapkan untuk pengambilan keputusan yang dilakukan dalam rangka pencapaian suatu tujuan.

Sedangkan bahan non buku adalah hasil pikiran manusia yang dituangkan tidak dalam bentuk cetak dan tidak pula tertulis seperti buku, koran, dll, melainkan dalam bentuk lain seperti :

\section{Rekaman Suara}

Sebuah media penyimpanan suara untuk merekam musik yang terus berkembang dari masa ke masa.

\section{Rekaman Video}

Merupakan metode penyimpanan rekaman gambar dan bunyi dalam bentuk pita magnetik, berbeda dengan film. Rekaman video juga digunakan untuk menyimpan data yang bersifst ilmiah, dan juga medis seperti data yang dihasilkan oleh elektrokardiogram.

\section{Kaset Audio Visual}

Layanan secara langsung bersentuhan dengan IT. Koleksi audio visual yang dimiliki adalah dalam bentuk CD, CD ROM, disket dan kaset, mikrofilm, mikrofis, piringan hitam, video kaset.

4. CD-ROM (Compact Disc Read Only Memori)

Alat dapat dibaca dengan bantuan komputer, berbentuk seperi disket dan dapat lebih banyak memuat data. Isinya biasanya dalam bentuk jurnal, juga ada 
yang merupakan bentuk peralihan dari media cetak untuk penyimpanan jangka panjang. Contoh : LISA, yang memuat literatur tentang ilmu perpustakaan dan informasi dari 550 terbitan berkala.

Dalam melakukan pengadaan diperlukan seleksi terlebih dahulu. Dalam melakukan pemilihan bahan non buku pustaka perlu dilakukan untuk menentukan nilai yang baik dari segi isi, maupun fisik bahan non buku pustaka tersebut. Ada beberapa kriteria secara umum yang perlu diperkirakan dalam melakukan penilaian bahan non buku, yaitu dari segi kualitas isi, kualitas teknis, kualitas fisik, dan prosedur/distributor. Untuk melakukan seleksi perlu alat bantu seleksi baik berfungsi sebagai alat verifikasi dan identifikasi.

Setalah melakukan seleksi berdasarkan kriteria yang telah ditentukan dengan menggunakan alat bantu seleksi, maka langkah selanjutnya adalah melakukan pengadaan. Seperti halnya buku dan majalah, pengadaan bahan non buku dapat dilakukan dengan cara pembelian, hadiah, dan pertukaran. Pembelian bahan non buku biasanya melalui orang yang menyalurkan produk tersebut dari pabrik. Sistem pesanan ada yang dilakukan dengan sistem approval plan, blanket order, ataupun standing order. Untuk pengadaan film dari luar negeri harus ada izin terlebih dahulu dari Departemen Luar Negeri agar bisa jebol dari badan sensor film. Berikut penjelasan lebih detail mengenai sistem pesanan :

1. Approvalplan : Perjanjian antara perpustakaan dengan penyalur, dengan mengijinkan penyalur secara otomatis mengirim copy Biaya Pembelian miliknya berdasarkan subyek/Biaya Pembelian khusus keperpustakaan

2. Blanket order : BP yang sudah dibeli tidak bisa dikembalikan, potongan harga tinggi.

3. Standing order : Sistem blanket order dimana penyalur mengirimkan BP dalam jumlah terbatas kepada perpustakaan untuk dibeli.

\section{B. Era revolusi 4.0}

Revolusi Industri 4.0 menunjukkan bahwa globalisasi atau suatu proses pada dunia internasioanal yang tidak hanya kejadiannya berdampak pada bidang teknologi saja, tetapi telah berinovasi berbagai di bidang lain seperti sosial budaya, tata kerja, hukum, lingkungan alam dan ekonomi. Akibat yang ditimbulkan dari inovasi atau istilah sekarang adalah dirupsi ini membuat tatanan dunia berubah drastis. Masalah yang terjadi pada saat ini maupun masa depan, tidak dapat diselesaikan dengan cara yang sama seperti dalam perencanaan yang lalu. Revolusi Indsutri 4.0 tidak mungkin hanya dihadapkan dengan pengembangan teknologi tanpa melibatkan pergerakan sosial di dalamnya. Selain menyiapkan daya saing yang unggul, perlu adanya kesadaran dan kebijakan masyarakat dalam menyikapi perkembangan dunia saat ini, ketika informasi banyak diakses tanpa kejelasan kebenarannya. Perlu dirumuskan strategi kebijakan nasional melalui kesadaran, kebijakan dan kedewasaan dalam berpikir. Informasi juga penting di telaah secara personal di masyarakat. Termasuk dalam bidang bahan non buku yang 
Published by Program Studi Perpustakaan dan IImu Informasi

FBS Universitas Negeri Padang, Indonesia

mungkin di era revolusi ini dibutuhkan strategi untuk pengadaanya.

C. Hasil wawancara dengan kepala perpustakaan Universitas Negeri Padang Dengan adanya berbagai macam koleksi yang ada diperustakaan membuat perpustakaan itu lebih menarik. karena menyediakan berbagai macam koleksi, dari bebagai macam koleksi yang ada diperpustakaan membuat perpustakaan itu menyediakan berbagai macan informasi yang lengkap untuk pemustaka, dengan begitu maka perpustakaan itu dianggap sangat baik dalam menyediakan bahan yang dibutuhkan oleh pemustaka, maka dari itu sebaiknya perpustakaan tidak hanya berusaha menyediakan bahan yang dibutuhkan oleh pemustaka tapi juga menyediakan bahan yang memang seharusnya ada diperpustakaan tersebut.

Mengelola bahan non buku itu dianggap rumit oleh pustakawan, dalam pengelolaan bahan non buku diperlukan keahliaan yang khusus dalam mengelolanya, pustakawan yang dibutuhkan harus paham betul akan jenis-jenis bahan yang ada dan teratur dalam mengikuti perkembangan teknologi untuk pengelolaan bahan koleksi non buku tersebut. Maka perpustakaan akan membutuhkan tenaga ahli khusus dalam mengelola bahan koleksi non buku tersebut dengan begitu maka akan membutuhkan dana yang besar. Dalam sistem pelayanan clossed access lebih cocok untuk sistem pelayanan karena pengadaan bahan non buku tersebut membutuhkan dana yang besar maka harus hati-hati dalam melakukan pelayanannya.

Dari hasil wawancara dengan kepala UPT Perpustakaan Universitas Negeri Padang. Dalam pengadaan bahan non buku UNP sudah tidak melakukan pengadaan lagi, pengadaan bahan non buku terakhir ada di UNP pada tahun 1992. Musnahnya koleksi bahan non buku di Universitas Negeri Padang akibat ketinggalan teknologi, sudah tidak adanya lagi alat baca untuk bahan non buku tersebut, ada dari alat untuk non buku tersebut yang sudah rusak dan tidak bisa lagi diperbaiki jika diperbaki pun orang yang akan memperbaiki pun juga sudah tidak ada dan dibeli orang yang menjual alat tersebut juga sudah tidak ada lagi. Selain itu pustakawan yang ahli dalam bidang tersebut sudah pensiun dan tidak ada yang bisa mengelolanya, dicari pegawai pustakawan yang baru merekapun juga tidak ahli dalam pengelolaan bahan non buku tersebut. Hal-hal tersebut lah yang menjadi penyebab sudah tidak adanya lagi koleksi bahan non buku diperpustakaan Universitas Negeri Padang.

Perpustakaan Universitas Negeri Padang fokus dalam pengadaan bahan pustaka seperti: buku wajib, buku referensi, terbitan berkala, terbitan pemerintah dan buku-buku yang bersifat hiburan atau rekreatif. Dengan cara pengadaan bahan perpustakaan di Universitas Negeri Padang melaui pemebelian dengan dana yang telah dialokasi kan oleh Universitas Negeri Padang kepada perpustakaan Universitas Negeri Padang, selanjutnya melalui sumbangan atau hadiah, dan melalui wajib simpan karya Ilmiah Civitas 
Akademika UNP. Buku yang mejadi perioritas dalam pengadaan adalah bukubuku yang sangat banyak peminatnya, buku-buku karya dosen Universitas Negeri Padang, dan buku-buku terbitan terbaru dan bersifat ilmiah.

Namun Universitas Negeri Padang pada saat ini tengah fokus pada rencana pembangunan perpustakaan pada tahun 2021, perpustakaan Universitas Negeri Padang akan menyediakan layanan berbentuk digital yang sesuai dengan kemajuan teknologi pada saat ini tidak lagi menyediakan layanan multi media seperti dulu lagi, UNP akan mengikuti zaman dalam sistem pengadaan maupun pengembangan bahan non buku tersebut. Dalam pengadaan bahan koleksi yang lain pun UNP juga akan melakukan sesuai dengan kemajuan teknologi agar bisa memberikan layanan terbaik kepada pengunjung perpustakaan Universitas Negeri Padang.

Pada saat ini UNP fokus dalam pembangunan perpustakaan UNP menjadi lebih baik, dari hasil wawancara kami dengan kepala perpustakaan Universitas Negeri Padang mengatakan bahwa perpustakaan UNP akan dibagun bioskop, ruangan musik karena pada zaman era revolusi 4.0 saat ini perpustakaan berubah fungsi mencakup sekaligus sebagai sarana rekreasi bagi pengunjung, rekreasi yang dimaksud adalah rekreasi yang berhubungan dengan ilmu pengetahuan dan menambah ilmu pengetahuan, sekaligus menyingkirkan anggapan bahwa perpustakaan itu tempat yang membosan kan, tempat yang serius, pelayanan yang kurang baik seperti pemustaka pemarah dan sebagainya.

\section{PENUTUP}

\section{Simpulan}

Dengan revolusi 4.0 ini perpustakaan Universitas Negeri Padang sebaiknya bisa menyediakan bahan non buku untuk kelengkapan informasi dalam perpustakaan Universitas Negeri Padang, dengan lengkapnya bahan koleksi diperpustakaan Universitas Negeri Padang membuat perpustakaan menjadi lebih siap dalam menghadapi perubahan revolusi 4.0 yang sangat berpengaruh dalam dunia pendidiakan untuk saat ini. Dan sebaiknya perpustaakn Universitas Negeri Padang menyediakan bahan non buku untuk keterlengkapan bahan perpustakaan. Dan layanan yang memang dibutuhkan sesuai dengan perkembangan zaman saat sekarang ini, karena saat ini perpustakaan bukan cuma menjadi sarana mencari pengetahuan atau tempat belajar namun juga mencakup menjadi sarana hiburan bagi pengunjung perpustakaan itu sendiri dengan baiknya dan cangihnya layanan diperpustakaan Universitas Negeri Padang makan itu akan menjadi daya tarik bagi mahasiswa, civitas UNP maupun masyarakat yang ada dilingkunganUniversitas Negeri Padang untuk berkunjung ke perpustakaan UNP.

\section{Saran}

1. Strategi yang diperlukan untuk pengadaan bahan non buku di Perpustakaan Pusat Universitas Negeri Padang adalah dengan melakukan inovasi atau yang disebut dalam istilah jaman sekarang dirupsi. Pembaruan-pembaruan terhadap bahan non buku yang fungsinya 
Published by Program Studi Perpustakaan dan IImu Informasi

sebagai media penyimpanan berupa informasi yang dapat mudah di akses oleh mahasiswa Universitas Negeri Padang.

2. Koleksi bahan non buku biasanya dipisahkan dari koleksi buku dan tidak dapat diakses sendiri oleh pemakai. Agar dapat meminimalisir hal-hal yang tidak diinginkan seperti, rusaknya bahan non buku, dan hilangnya bahan non buku tersebut. Hal ini juga dapat diantisipasi dari segi keamanan yang ada diperpustakaan dengan meningkatkan setiap sistem keamanan.

3. Selain itu Perpustakaan Universitas Negeri Padang tidak lagi menggunakan pengadaan bahan non buku, terakhir pengadaan tersebut dilakukan tahun 1992. Dikerenakan terdapat kendala dari alat-alat yang kurang memadai, sehingga pencari informasi beralih ke internet, seperti youtube.

4. Alat-alat tersebut telah rusak dan musnah. Terutama pada saat era revolusi ini semua beralih ke media elektronik.

5. Meningkatkan kinerja dari para pustkawan dan sistem keamanan perpustakaan di pusat maupun fakultas di Universitas Negeri Padang.

6. Pustakawan yang ahli dalam bidang tersebut sudah pensiun dan tidak ada yang bisa mengelolanya, dicari pegawai pustakawan yang baru merekapun juga tidak ahli dalam pengelolaan bahan non buku tersebut. Hal-hal tersebut lah yang menjadi penyebab sudah tidak adanya lagi koleksi bahan non buku diperpustakaan Universitas Negeri Padang

7. Pada saat sekarang ini mahasiswa UNP belum menggunakan non buku tetapi perpustakaan akan mendirikan non buku kembali yang lebih bervariasi. UNP akan mendirikan di lantai 6 (enam) seperti bioskop yang di mana di dalam bioskop tersebut menayangkan film yang berpendidikan dan bersejarah agar mahasiswa mendapatkan pengetahuan lebih banyak lagi.

\section{DAFTAR PUSTAKA}

Banu Prasetyo, U. T. (2013). Revolusi Industri 4.0 dan Tantangan Perubahan Sosial. SEMATEKSOS 3, 1-6.

Betriati, M. (2015, September). Penyiangan Koleksi Bahan Pustaka Di kantor Arsip, Perpustakaan Dan Dokumentasi Kota Padang. Ilmu Informasi Perpustakaan dan Kearsipan, IV, 1-6.

Fatimah. (2019). Pengadaan Bahan Pustaka Sebagai Upaya Dalam Memenuhi Kebutuhan Pemustaka. Imam Bonjol: kajian ilmu informasi dan perpustakaan, 1-6.

Rahmah, E. (2012). Manajemen Pengembangan Koleksi. Padang: Sukabina Press.

Sudirman Anwar, S. M. (2017). Manajemen Perpustakaan. Jakarta: Indra Press.

Suhendri, C. (2019). Registrasi Dan Pengolalan buku si Perpustakaan Balai Penelitian Ternak. Temu Teknis Jabatan Fungsional Non peneliti, 1-6.

Syahyuman. (2012). Manajemen Koleksi Perpustakaan. Padang: Sukabina Press.

Yolanda F. Waas, D. A. (2017). Manfaat Pengadaan Bahan Pustaka Dalam Memenuhi Kebutuhan Informasi Pemustaka di Perpustakaan dan Arsip 
Published by Program Studi Perpustakaan dan Ilmu Informasi FBS Universitas Negeri Padang, Indonesia

Derah Kabupaten Nabire. Acta Diuma, VI, 1-18.

Yunita, E. (2011, Desember 5).

Pengadaan Bahan Pustaka Di

Perpustakaan Arsip Nasional Republik Indonesia. UIN Syrif Hidayatullah Jakarta, pp. 1-96.

(Writing style: APA $6^{\mathrm{TH}}$ ed., Cambria 12, Reguler, spasi 1.5 , spacing before $6 \mathrm{pt}$, after $6 \mathrm{pt}$ ). 